\title{
Influence of temperature and light conditions on dry-matter distribution, development rate and yield in arable crops ${ }^{1}$
}

\author{
W. H. VAN DOBBEN \\ Institute for Biological and Chemical Research on Field Crops and Herbage, \\ Wageningen, Netherlands
}

\section{Summary}

The distribution of dry matter over the various organs of a plant is not only important for the evaluation of the product finally harvested, but also for the growth rate and yield level. Differences in growth rate between species and even varieties are mainly due to the rate at which newly produced matter is converted to assimilating tissue and by the green area formed per unit of dry-matter weight. Shoot/root-ratio and moisture content in the plant show a certain correlation to growth rate, as can be established from the light response and temperature effects.

As regards temperature, the final size of a plant is determined by mutually independent effects on growth rate and rate of development.

In temperate zone crops a warm climate (for instance $25^{\circ} \mathrm{C}$ ) shortens the period of development without giving sufficient compensation by faster growth. As a result, the plants remain smaller than in a cool climate. In crops of subtropical origin (maize, beans) the growth rate is stimulated to such an extent under warm conditions that the plants grow larger despite the short growth period. This vigorous growth at high temperatures can be explained by a great increase in shoot/root-ratio, which is not shown by temperate zone plants (small cereals, peas and flax). The influence of phasic development on final yield is also demonstrated by photoperiodism. Optimal photoperiods give a fast development and too short a growing period. The best yields are obtained with suboptimal photoperiods.

\section{The distribution of material in a mature crop}

The various parts of a crop plant are evaluated very differently and in practice the term "yield" is often limited to specific organs. The potato haulm is worthless and even a nuisance at the harvest. The seed of cereals is more highly esteemed than the straw. These examples show that the division of dry matter over different parts of the plant is as important as the total yield. An "increase in yield" resulting from the use of better varieties may be limited to a shift in the distribution of dry matter to more valuable organs without an increment in total yield. This is clearly the case in the sequence of wheat varieties in the Netherlands since 1900 (TABLE 1). Since it is difficult to raise total production without lengthening the life of a crop, it is doubtful whether it would have been possible to raise the kernel yield of wheat by breeding work without such a shift from vegetative organs to kernel.

1 Lecture held at the course "Fundamentals of dry-matter production and distribution" organized by the Royal Netherlands Society for Agricultural Sciences, Wageningen, 10th January, 1962. 
TABLE 1. Total yield and kernel/straw-ratio of leading winter-wheat varieties in the Netherlands; average from experimental fields in the province of Groningen

\begin{tabular}{lccc}
\hline Variety & Period & $\begin{array}{c}\text { Weight of straw } \\
+ \text { kernel }(\mathbf{k g} / \mathrm{ha})\end{array}$ & $\begin{array}{c}\text { Kernel/straw } \\
\text {-ratio }\end{array}$ \\
Wilhelmina $\ldots \ldots \ldots$ & $1902-1932$ & 12600 & 0,51 \\
Juliana $\ldots \ldots \ldots \ldots$ & $1934-1947$ & 12430 & 0,55 \\
Staring $\ldots \ldots \ldots \ldots$ & $1948-1961$ & 13900 & 0,59 \\
Felix $\ldots \ldots \ldots \ldots$ & $1958-1961$ & 12830 & 0,60 \\
Heines VII $\ldots \ldots \ldots$ & $1953-1955$ & 11860 & 0,66 \\
\hline
\end{tabular}

Spring barley is equal to other cereals because of its high kernel/straw-ratio. The total yield is distinctly inferior, this being due to the relatively short growing period of this crop.

The final yield of specific organs is the result of production and distribution of matter in subsequent phases of plant development. Even when distribution under suitable conditions is a constant function of time per phase (as claimed by VAN DE SANDE BAKHUYZEN, 1937 and WiTtenRood, 1957), distribution in the final yield may be variable owing to the variable share of each phase in total production. Moreover, distribution within a phase depends on environmental factors.

\section{The influence of the dry-matter distribution on plant growth}

It is well known that the growth rate shows great specific differences and largely depends on climatic conditions. Generally speaking, however, it is impossible to explain this by differences in photosynthesis. According to HeATH and Gregory (1938) several field crops do not differ substantially in assimilation rate. Although WAtson (1947) observed differences in assimilation rate between crops under field conditions, at present it is generally assumed that related species at least (for instance cereals) show no significant differences in the rate of photosynthesis per leaf unit (cf. for example for the genus Triticum BeLikov et al., 1961).

According to GaAstra (1959) photosynthesis is only slightly dependent on temperature when $\mathrm{CO}_{2}$-concentration or light intensity is the limiting factor in the process. It may be assumed that specific and climatic fluctuations in growth rate are due to formative processes, especially the rate at which newly produced matter is converted to assimilating tissue. Plants may use newly formed matter either for organs involved in photosynthesis or for non-assimilating organs, for instance roots and parts of stems. It may also be stored in the form of carbohydrates.

When a certain quantity of dry matter is converted to assimilating tissue its efficiency still depends on cell elongation. The assimilating area per gram of dry matter is more or less inversely proportional to the dry-matter content of the tissue. At temperatures below $10^{\circ} \mathrm{C}$ in particular this content is high (TABLES 2 and 4) and it retards growth. At very low temperatures the dry-matter content is also affected by a sugar reserve which in young wheat plants may rise to $20 \%$ in the dry matter (MILLER, 1939). As a result growth is kept at a low level. As to specific differences it is significant that at low temperatures wheat always has a higher dry-matter content and a slower growth rate than rye.

From the ecological point of view this high dry-matter content and winter sugar reserve is important for increasing frost resistance and limiting growth, so that a 
INFLUENCE OF TEMP. AND LIGHT COND. ON DRY-MATTER DISTRIB., DEVELOPM. RATE AND . .

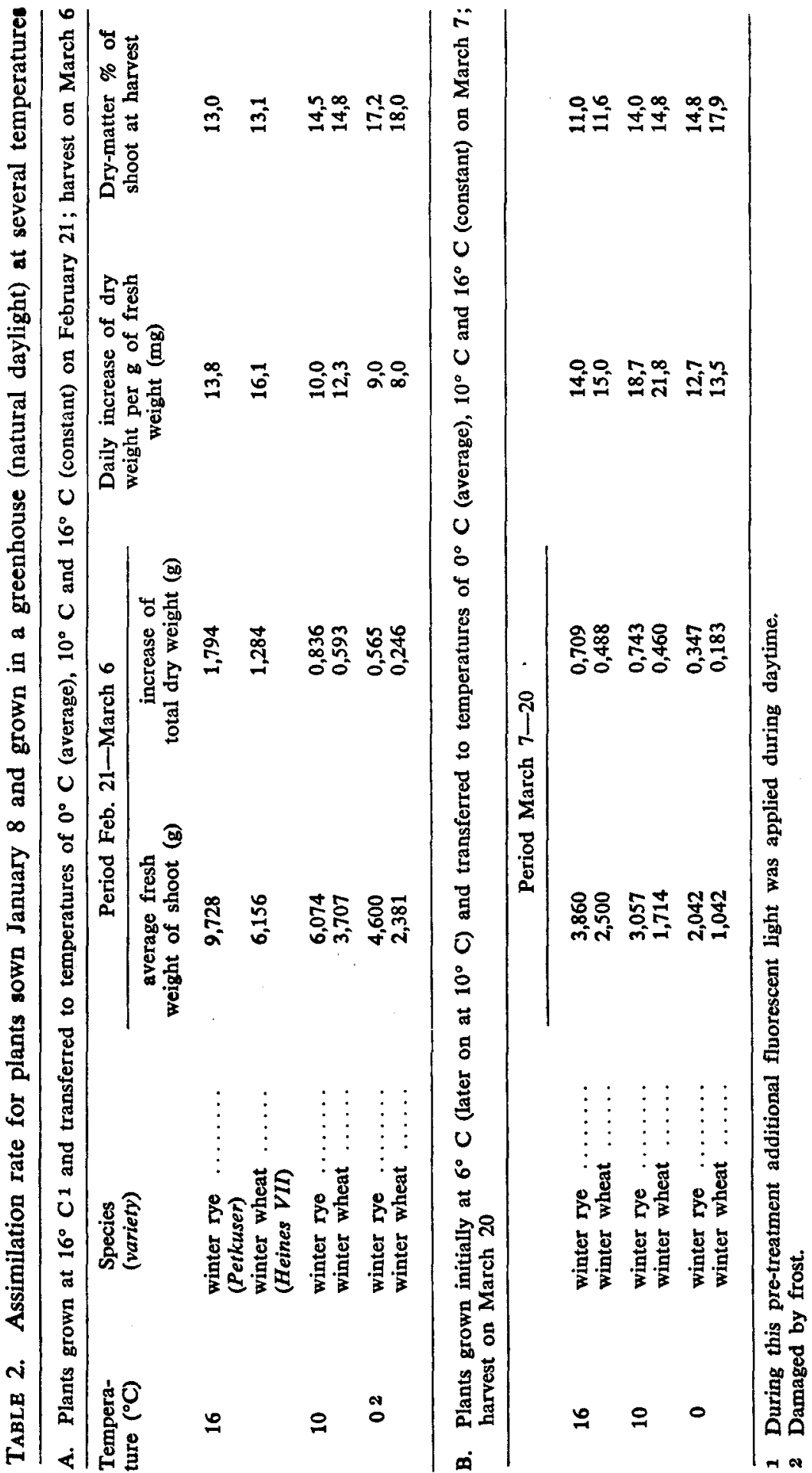

Neth. J. agric. Sci., Vol. 10 (1962) No. 5 Special Issue 
compact rosette develops which is well adapted to cope with the perils of the cold season.

At normal temperatures the shoot/root-ratio is probably the most important factor regulating growth rate. There are indications that differences in growth between varieties can be explained by a different shoot/root-ratio and dry-matter content (TABLE 3). Related species (small cereals, for example) also show a correlation between shoot/root-ratio and growth rate. It is well known that rye grows faster than barley and wheat. These crops show a decreasing shoot/root-ratio in this sequence. TABLE 4 gives some figures for winter rye and winter wheat (the influence of temperature on shoot/root-ratio will be discussed later).

TABLE 3. Fresh weight, dry weight and shoot/root-ratio of 3 winter-wheat selections showing differences in vegetative growth in early spring. Date April 12

\begin{tabular}{lcccc}
\hline Selection & $\begin{array}{c}\text { Fresh weight } \\
\text { of shoots }(g)\end{array}$ & $\begin{array}{c}\text { Dry-matter } \\
\text { content (\%) }\end{array}$ & $\begin{array}{c}\text { Dry weight } \\
\text { of shoots (g) }\end{array}$ & $\begin{array}{c}\text { Shoot/root } \\
\text {-ratio }\end{array}$ \\
MGH $\ldots \ldots$ & 6,4 & 16,2 & & 1,04 \\
GB $\ldots \ldots$ & 5,6 & 18,0 & 0,99 & 1,4 \\
HC $\ldots \ldots$ & 4,9 & 17,1 & 0,84 & 1,3 \\
\hline
\end{tabular}

TABLE 4. Shoot/root-ratio of winter wheat and winter rye sown January 8 in a greenhouse at different temperatures and complete nutrition

\begin{tabular}{|c|c|c|c|c|c|c|}
\hline $\begin{array}{l}\text { Temper- } \\
\text { ature }\left({ }^{\circ} \mathrm{C}\right)\end{array}$ & $\begin{array}{l}\text { Species } \\
\text { (variety) }\end{array}$ & $\begin{array}{c}\text { Age } \\
\text { (days) }\end{array}$ & $\begin{array}{c}\text { Leaf } \\
\text { number }\end{array}$ & $\begin{array}{l}\text { Total dry matter } \\
\text { (mg/plant) }\end{array}$ & $\begin{array}{l}\text { Dry matter } \\
\text { of tops }(\%)\end{array}$ & $\begin{array}{c}\text { Shoot/root } \\
\text {-ratio }\end{array}$ \\
\hline \multirow[t]{3}{*}{$6-10 *$} & $\begin{array}{l}\text { winter rye } \\
\text { (Petkuser) }\end{array}$ & 58 & 4,4 & 167 & 15,7 & 2,2 \\
\hline & $\begin{array}{l}\text { winter wheat } \\
\text { (Heines VII) }\end{array}$ & 58 & 3,7 & 105 & 16,2 & 2,0 \\
\hline & $\begin{array}{l}\text { winter rye } \\
\text { winter wheat }\end{array}$ & $\begin{array}{l}71 \\
71\end{array}$ & $\begin{array}{l}5,8 \\
5,3\end{array}$ & $\begin{array}{l}667 \\
350\end{array}$ & $\overline{17,0}$ & $\begin{array}{l}2,4 \\
2,1\end{array}$ \\
\hline 16 & $\begin{array}{l}\text { winter rye } \\
\text { winter wheat } \\
\text { winter rye } \\
\text { winter wheat }\end{array}$ & $\begin{array}{l}36 \\
36 \\
49 \\
49\end{array}$ & $\begin{array}{l}5,4 \\
4,0 \\
7,0 \\
6,6\end{array}$ & $\begin{array}{r}490 \\
311 \\
2284 \\
1595\end{array}$ & $\begin{array}{r}9,5 \\
9,6 \\
13,0 \\
13,1\end{array}$ & $\begin{array}{l}4,4 \\
3,1 \\
6,7 \\
3,7\end{array}$ \\
\hline
\end{tabular}

* Seedling growth initially at $6^{\circ} \mathrm{C}$, later on at $10^{\circ} \mathrm{C}$.

In order to compare the assimilation rates of the two species at various temperatures rye and wheat plants were grown as seedlings in a greenhouse. The plants were then divided into 3 groups and grown at temperatures of $16^{\circ} \mathrm{C}, 10^{\circ} \mathrm{C}$ and about $0^{\circ} \mathrm{C}$. After 13 days the increases in dry weight were divided by the average fresh weight in the same period so as to obtain a growth rate per unit of assimilating tissue (TABLE 2). Rye shows a somewhat lower assimilation rate than wheat, possibly as a result of more mutual shading of leaves ${ }^{1}$, but it is obvious that the faster growth of rye is not caused by higher assimilation. This supports the theory

1 Table 2 does not enable any conclusions to be drawn on the influence of temperature on assimilation. The highest figures were obtained in cases in which there was no change in temperature (a: $16^{\circ} \mathrm{C}, \mathrm{b}: 10^{\circ} \mathrm{C}$ ), indicating that transfer caused a shock. 
that the main reason for this phenomenon is to be sought in the distribution of material over the plant parts.

In the following sections special attention will be given to the influence of light and temperature on growth rate and it will be shown that dry-matter distribution and especially shoot/root-ratio again have a decisive influence. The data on growth and shoot/root-ratio were obtained by periodical sampling of plants grown at constant temperatures but under natural light.

\section{Determination of shoot/root-ratio and growth rate during vegetative growth}

Shoot-root-ratio and growth rate change during development. In most annual plants the following pattern can be observed under optimal conditions. During germination root growth first dominates to such an extent that the shoot/root-ratio is low. In the seedling stage the shoot overtakes the root and the distribution established at the end of this stage remains almost constant during subsequent vegetative development (FIG. 1). During the transition to the generative stage the shoot/root-ratio shows a sharp increase as a symptom of a new distribution pattern more favourable for the tops. In each phase of development the points obtained when the shoot and root figures are plotted together form approximately straight lines, showing that there is no substancial change in the distribution within a phase.

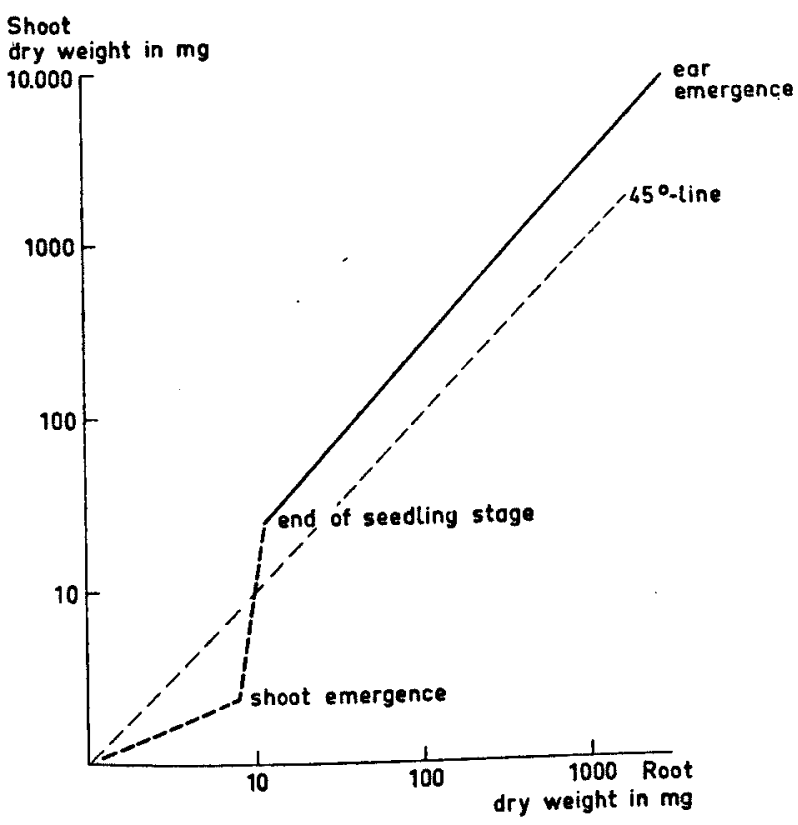

Fig. 1.

Shoot/root-ratio in a rye plant grown under optimal conditions in daylight at a constant temperature of $10^{\circ} \mathrm{C}$. Logarithmic scale; i.e. all observations with the same shoot/root-ratio lie on $45^{\circ}$-lines

The shoot/root-ratio figures from TABLES $3-6$ correspond to a point of reference in the middle of the post-seedling vegetative stage. The growth-rate figures (TABLES 7 and 9) were taken from the same stage. The increase in weight for free-standing plants is exponential and therefore gives straight lines when plotted logarithmically 
against time (FIG. 2). It shows that for peas and other crops with large seeds seedling growth is relatively more vigorous than growth in the subsequent vegetative stage. In the case of cereals this is only true for the high temperatures.

The growth rate figures (TABLE 7) refer to the gradients of the lines representing the post-seedling stage. They indicate the number of days in which dry weight increases tenfold. The figures thus obtained are inversely proportional to growth rate. It should be emphasised here that this rate only applies to a certain period of development and is not the only factor determining the ultimate yield. In the generative phase growth rate is considerably slowed down owing to the formation of nonassimilating tissue. The figures in TABLE 7 and 9 can be used, however, to demonstrate the specific differences and the influence of environmental factors.

dry weight

in $\mathrm{mg}$

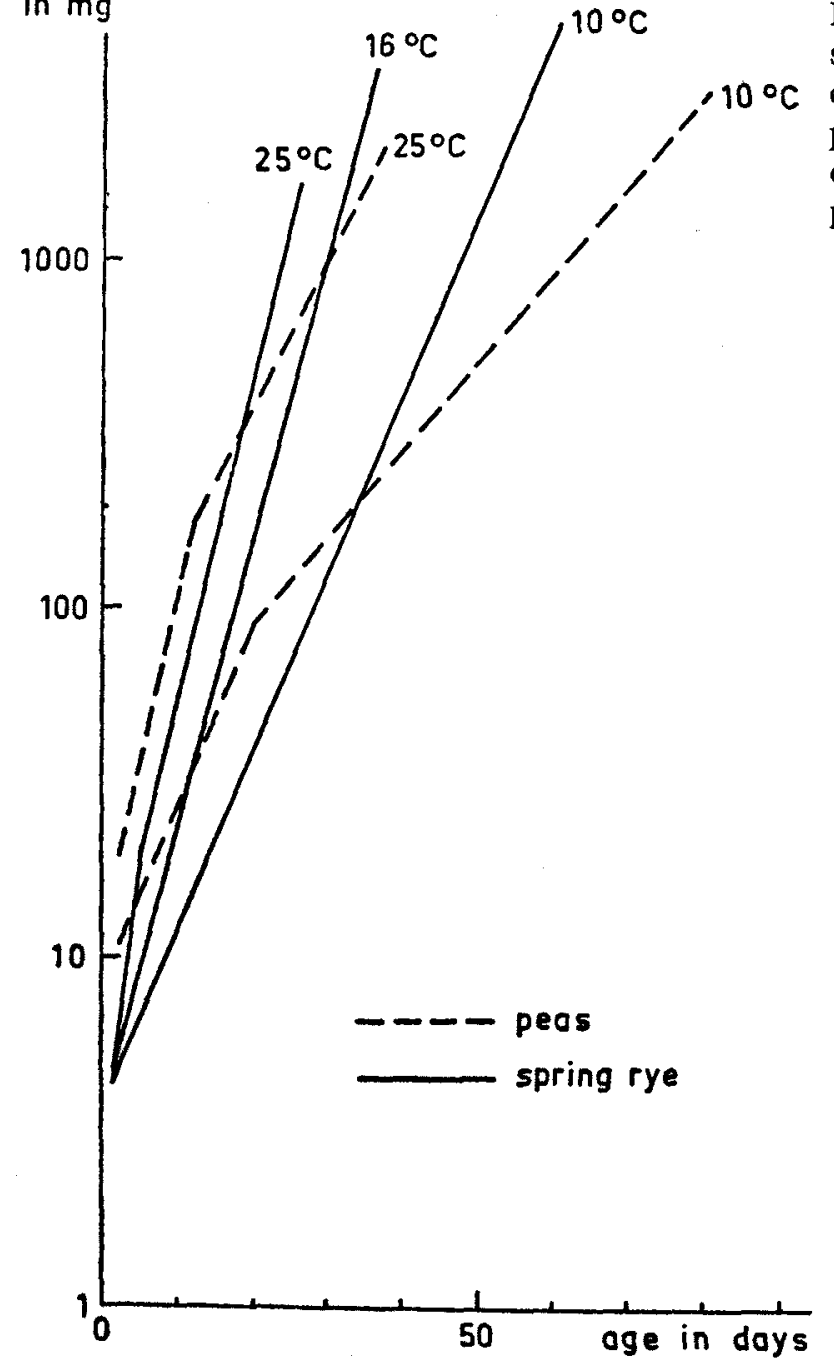

FIG. 2.

Increase in dry weight of pea and spring rye plants grown under optimal conditions at several temperatures. Logarithmic scale for ordinate. Seedling and vegetative post-seedling stage 


\section{The influence of light on distribution of material in the plant}

Light intensity and light-colour influence the distribution of dry matter in the plant. Many light responses can be understood in this way. In etiolated shoots stem growth is maximal but leaf development is suppressed. When the shoots are illuminated relationships are presumably inverted by a different distribution of matter among the stem and leaves.

The vigorous growth of shoots in the absence of light corresponds to a high shoot/ root-ratio. Apparently the material available is used as far as possible for stem growth and this, combined with a maximum cell elongation, gives the shoot a better chance to reach full daylight.

It is well known that light colour has a formative influence on plants. Downs, HENDRICKS and BorTHWICK (1957) have shown that "far red" radiation given in the dark period may elongate shoots and leaves. The results of our own experiments indicate that shoot elongations of this kind can be connected with an increased shoot/root-ratio (TABLE 5). Both incandescent filament lamps and low-pressure mercury lamps emit a great deal of "far red". Under these lamps plants develop relatively long and weak leavves. Shoot yield is above and root yield below the yield

TABLE 5. Influence of additional irradiation on yield and shoot/root-ratio of young plants of Petkuser winter rye sown January 16 in a greenhouse at $16^{\circ} \mathrm{C}$ and harvested February 12

\begin{tabular}{|c|c|c|c|c|c|}
\hline \multirow[t]{2}{*}{ Lamp type } & \multirow{2}{*}{$\begin{array}{l}\text { Daily irradia- } \\
\text { tion (p.m.-a.m.) }\end{array}$} & \multicolumn{2}{|c|}{ Dry weight (mg/plant) } & \multirow{2}{*}{$\begin{array}{l}\text { Dry matter } \\
\text { of tops }(\%)\end{array}$} & \multirow{2}{*}{$\begin{array}{l}\text { Shoot/root } \\
\text {-ratio }\end{array}$} \\
\hline & & tops & roots & & \\
\hline - (controls) & - & 87,0 & 27,0 & 9,8 & 3,2 \\
\hline Incandescent lamp $25 \mathrm{~W} \ldots$ & $0-24$ & 98,4 & 16,5 & 8,5 & 5,9 \\
\hline $\begin{array}{l}\text { Low pressure mercury lamp } \\
250 \mathrm{~W}\end{array}$ & $7-19$ & 116,3 & 20,0 & 9,4 & 5,8 \\
\hline $\begin{array}{l}8 \text { fluorescent tubes } 60 \mathrm{~W} . \\
\text { (Philips No. 33) }\end{array}$ & $7-19$ & 166,0 & 52,2 & 10,6 & 3,2 \\
\hline
\end{tabular}

of controls, so that the shoot/root-ratio is considerably higher. When these plants are allowed to continue growing they gain an advantage over the controls in total yield which is readily explained by the larger leaf area. The low figures for drymatter content indicate that "far red" radiation also stimulates the cell elongation that contributes to the formation of a large assimilating area. A fairly strong additional illumination with fluorescent tubes (without much far red) increases the yield considerably by high light intensity but does not influence the shoot/root-ratio.

Apparently the influence of light colour is especially important when the basic illumination is weak, for instance daylight in winter (in our own experiments) or a short daily illumination (Downs et al., 1957).

The effect is also specific. In peas an elongation of the stem can be obtained with "far red", but the shoot/root-ratio is not affected.

\section{The influence of temperature on the distribution of material in the plant}

It can be concluded from the results presented in TABLES 4 and 6 that the shoot/ root-ratio generally increases with temperature. This has also been observed by KHALIL (1956). At temperatures just above zero cereals and peas show ratios between 1 and 2 . In the range $10-16^{\circ} \mathrm{C}$ much higher values are reached with great specific 
TABLE 6. Shoot/root-ratio for plants grown in sandy soil with optimal mineral and water supply in greenhouses at several temperatures; sowing dates: Feb. 1 $\left(10^{\circ} \mathrm{C}\right)$, Feb. $28\left(16^{\circ} \mathrm{C}\right)$ and March $16\left(25^{\circ} \mathrm{C}\right)$

\begin{tabular}{ccccccccc}
\hline $\begin{array}{c}\text { Tempera- } \\
\text { ture }\left({ }^{\circ} \mathrm{C}\right)\end{array}$ & $\begin{array}{c}\text { Spring } \\
\text { rye } \\
\text { (Petkuser) }\end{array}$ & $\begin{array}{c}\text { Spring } \\
\text { wheat } \\
(\text { Peko) }\end{array}$ & $\begin{array}{c}\text { Spring } \\
\text { bariey } \\
\text { (Herta) }\end{array}$ & $\begin{array}{c}\text { Oats } \\
\text { (Marne) }\end{array}$ & $\begin{array}{c}\text { Peas } \\
\text { (Rondo) }\end{array}$ & $\begin{array}{c}\text { Flax } \\
\text { (Wiera) }\end{array}$ & $\begin{array}{c}\text { Maize } \\
\text { (Pioneer m.) }\end{array}$ & $\begin{array}{c}\text { Beans } \\
(\text { Beka) }\end{array}$ \\
10 & 2,5 & 1,5 & 1,7 & 2,2 & 2,0 & 3,5 & - & - \\
16 & 6,0 & 3,0 & 3,0 & 4,0 & 3,0 & 6,0 & 3,0 & 4,5 \\
25 & 6,0 & 4,2 & 3,0 & 4,0 & 3,5 & 7,0 & 5,0 & 8,0 \\
\hline
\end{tabular}

Note. To satisfy daylength requirements for long-day species extra light hours were supplied by single fluorescent tubes (Philips No. 33).

differences. Between $16^{\circ}$ and $25^{\circ} \mathrm{C}$ several species seem to show a maximum or at least no further increase. The same applies to growth rate (TABLE 7). There are distinct differences between temperate zone crops and such subtropical crops as maize and beans. The latter only start growing at about $10^{\circ} \mathrm{C}$. At higher temperatures the shoot/root-ratio and growth rate increase without reaching an optimum value within the range of our investigations.

TABLE 7. Number of days in which the dry weight of juvenile plants increased tenfold under optimal conditions; the figures are inversely proportional to the growth rate

\begin{tabular}{ccccccccc}
\hline $\begin{array}{c}\text { Tempera- } \\
\text { ture }\left({ }^{\circ} \mathrm{C}\right)\end{array}$ & $\begin{array}{c}\text { Spring } \\
\text { rye }\end{array}$ & $\begin{array}{c}\text { Spring } \\
\text { wheat }\end{array}$ & $\begin{array}{c}\text { Spring } \\
\text { barley }\end{array}$ & Oats & Peas & Flax & Maize & Beans \\
10 & 22 & 32 & 20 & 23 & 42 & 27 & - & \\
16 & 14 & 22 & 12 & 20 & 27 & 23 & 19 & 33 \\
25 & 13 & 20 & 11 & 18 & 23 & 20 & 9 & 15 \\
\hline
\end{tabular}

Comparison of TABLES 6 and 7 shows a clear agreement in temperature response between shoot/root-ratio and growth rate. This is strong evidence that the response of growth to temperature is mainly governed by shifts in the shoot/root-ratio.

\section{The influence of temperature on growth, development and the final plant weight}

The yield is determined by both the growth rate and the length of the growth period. This period depends on the rhythm of development. The effect of the temperature on the length of the period from emergence to flowering is independent of the effect of temperature on growth. The mutual independence of growth and development has been emphasized in Russian work on phasic development, especially that done by Lysenko. This concept seems to provide a good explanation of the influence of temperature on the final crop yield.

When the temperature is raised from $16^{\circ}$ to $25^{\circ} \mathrm{C}$ vegetative growth in small cereals and peas is distinctly accelerated in the seedling, but only slightly in the fol. lowing stage ${ }^{1}$ (TABLE 7), whereas development is speeded up considerably (TABLE 8). As a result the plants remain smaller at $25^{\circ} \mathrm{C}$ as compared to $16^{\circ} \mathrm{C}$ (FIG. 3 and 5).

1 In this connection it should be observed that seedling growth mainly depends on kernel reserves; this may explain its higher temperature optimum. 
Figures 3-7 


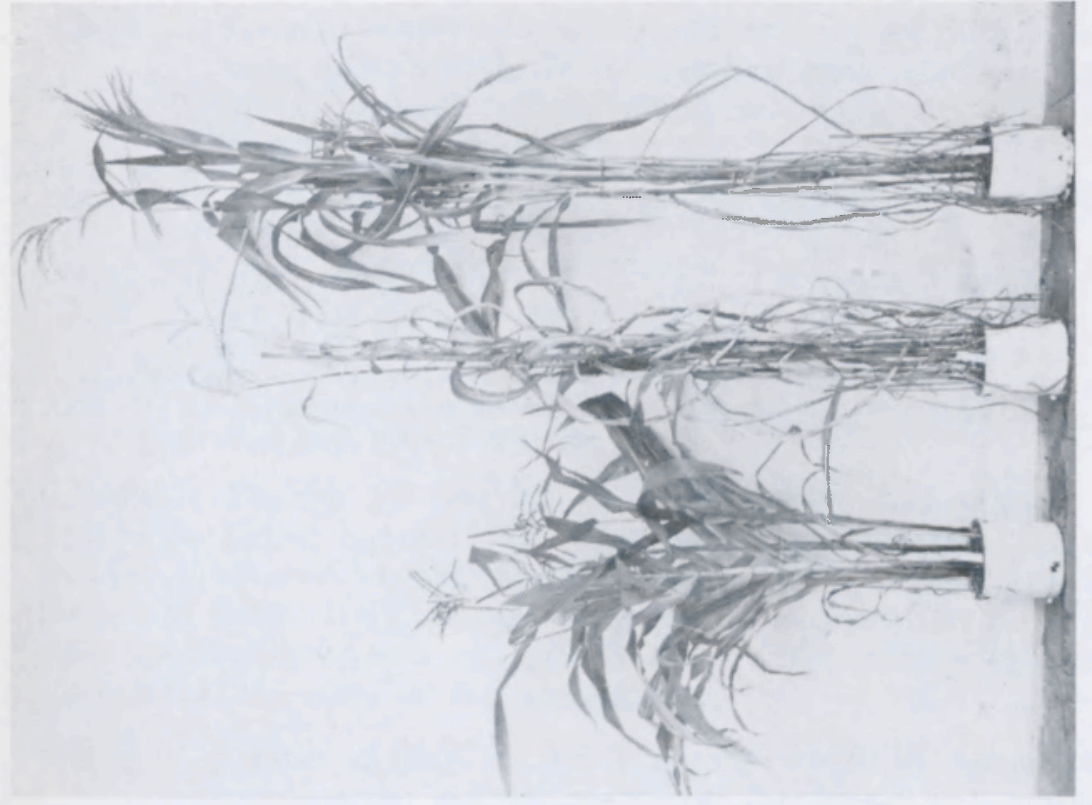

항흔

난 들

등..

ज证

인

$\leftarrow 0$

ह 인

는

i ำ.

N $m$ 는

हก त

ก 1

ง 1 ह

$\rightarrow$ 을

ن

$+$

这

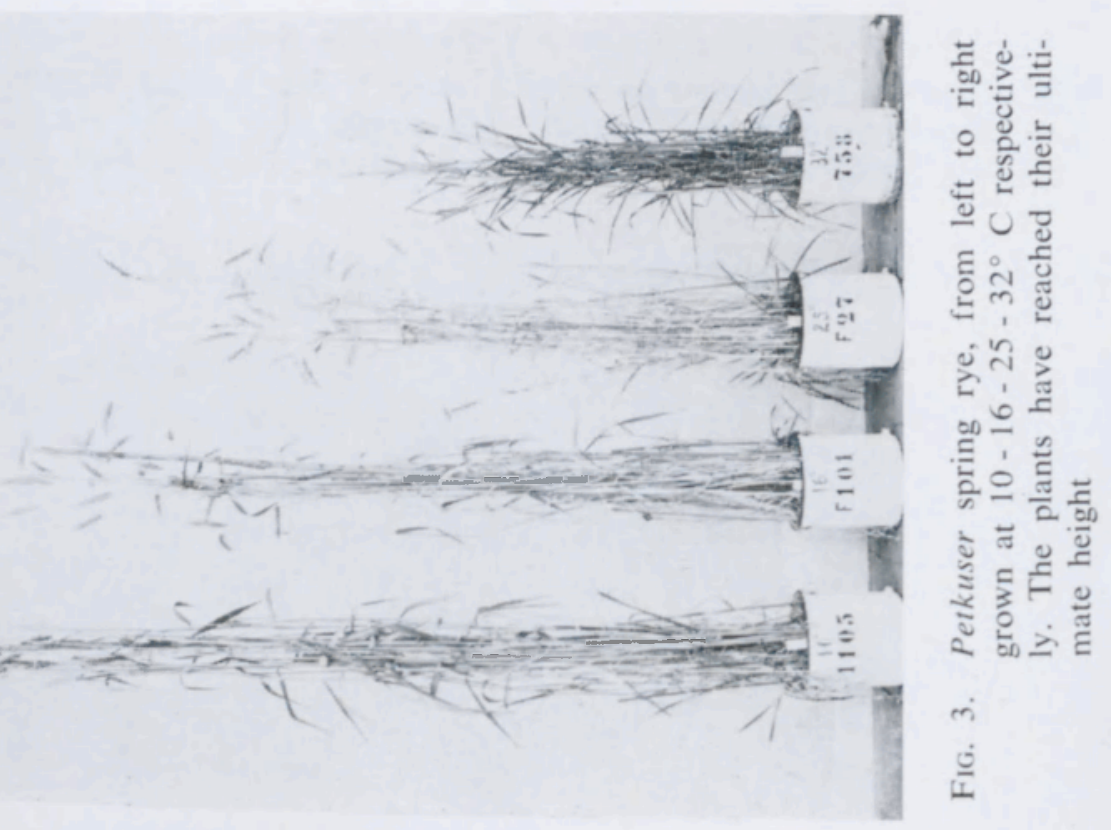


Fig. 5. Rondo peas grown at $16^{\circ} \mathrm{C}$ (left) and $25^{\circ} \mathrm{C}$ (right); photographed at the beginning of flowering

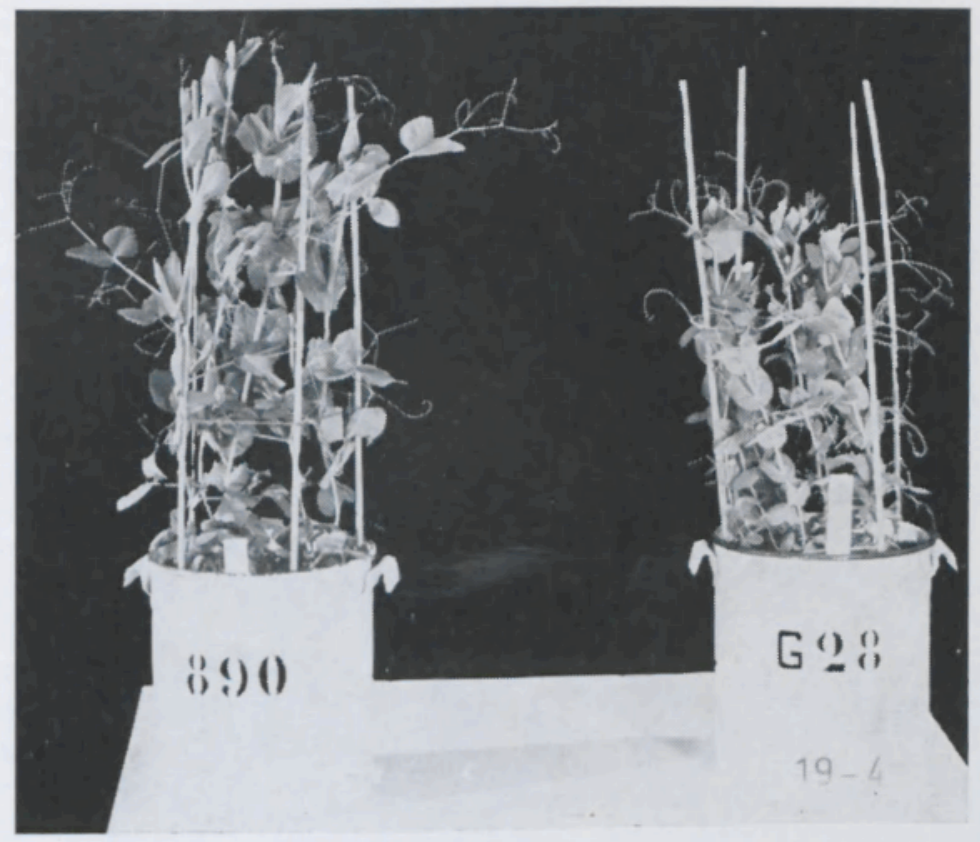

Fig. 6. Beka beans grown at $16^{\circ} \mathrm{C}$ (left) and $25^{\circ} \mathrm{C}$ (right); photographed at the beginning of flowering

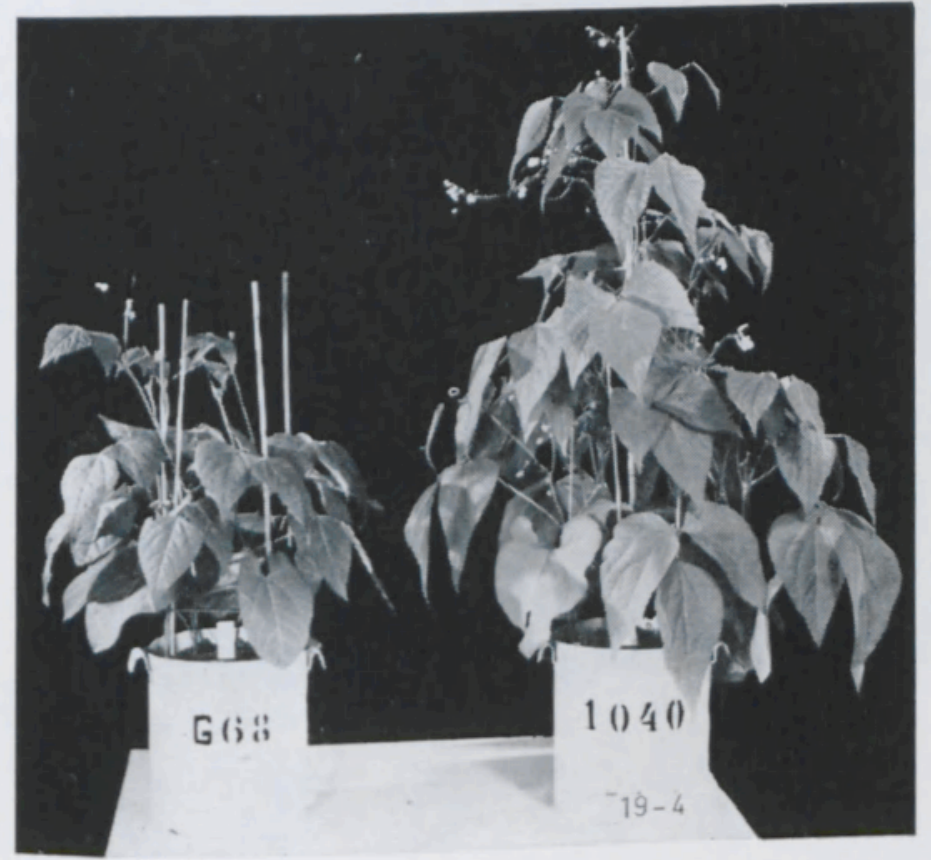




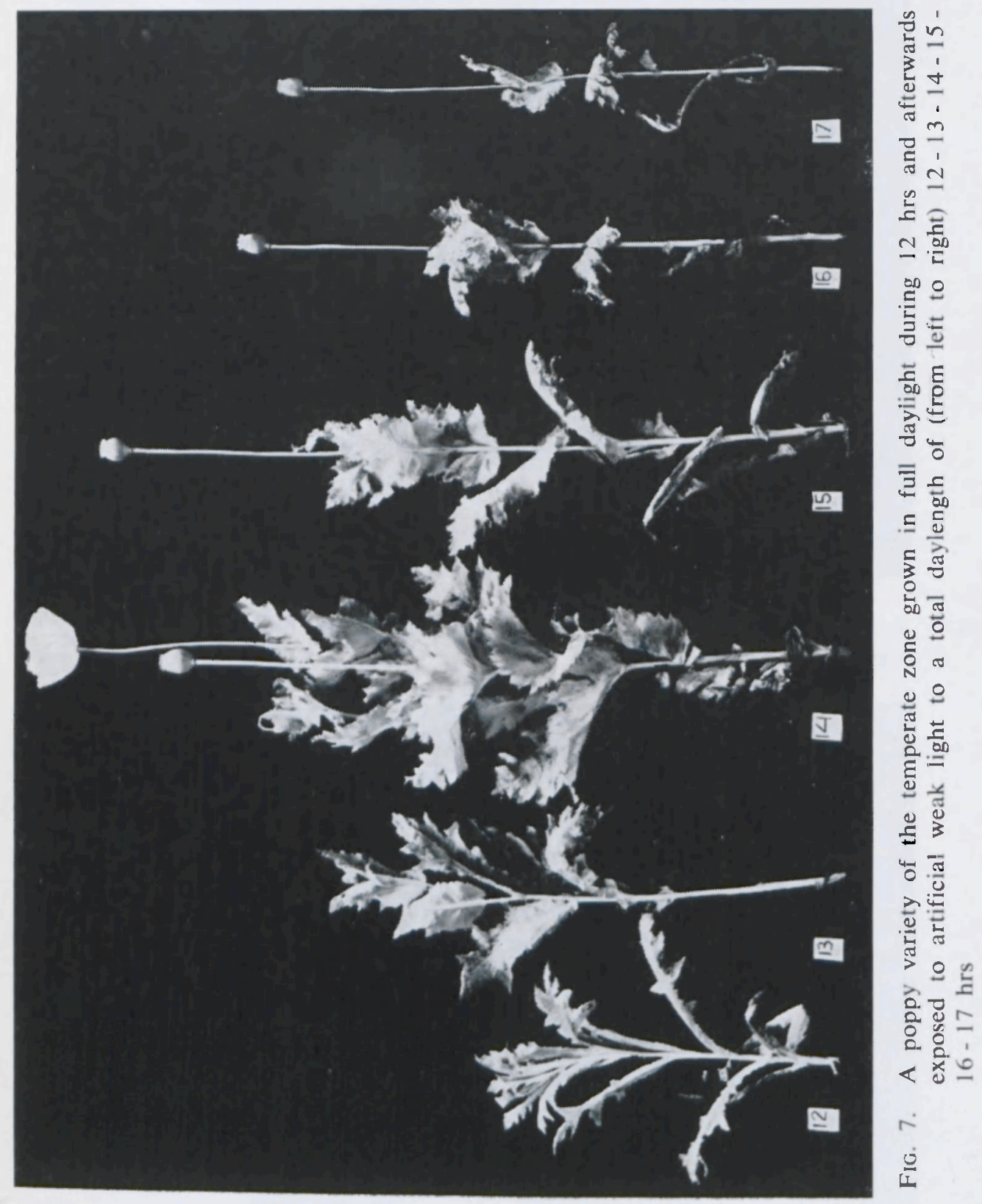


INFLUENCE OF TEMP. AND LIGHT COND, ON DRY-MATTER DISTRIB., DEVELOPM. RATE AND .

TABLE 8. Number of days from emergence until heading (cereals) or flowering

\begin{tabular}{ccccccccc}
\hline $\begin{array}{c}\text { Tempera- } \\
\text { ture }\left({ }^{\circ} \mathrm{C}\right)\end{array}$ & $\begin{array}{c}\text { Spring } \\
\text { rye }\end{array}$ & $\begin{array}{c}\text { Spring } \\
\text { wheat }\end{array}$ & $\begin{array}{c}\text { Spring } \\
\text { barley }\end{array}$ & Oats & Peas & Flax & Maize & Beans \\
10 & 82 & 129 & 99 & 115 & 86 & 100 & & \\
16 & 51 & 70 & 63 & 68 & 52 & 65 & 87 & 46 \\
25 & 37 & 57 & 52 & 50 & 37 & 50 & 50 & 24 \\
\hline
\end{tabular}

At our institute BrouWER (1959) demonstrated this temperature effect for the first time with peas. The relation between temperature and final plant weight has been discussed by LUNDEGARDH (1954) who observed that the temperature optimum for the final size of rye is much lower than for seedling growth. His explanation that the growth optimum of rye decreases during development is not satisfactory. The temperature determines the ultimate size as the result of a mutually independent influence of temperature on growth (daily increment in weight) and development (length of the growth period). For small cereals and peas the time available for production is reduced by a rise in temperature without being sufficiently compensated by more vigorous growth, so that the plants remain smaller when the temperature is higher.

When the temperature is raised from 10 to $16^{\circ} \mathrm{C}$ the rates of growth and development are accelerated stronger than in the range $16-25^{\circ} \mathrm{C}$ but in this case the rate of development also shows the highest figures (TABLE 9). As a result the plant size is expected to decrease at about the same rate as in the range $16-25^{\circ} \mathrm{C}$.

In the case of our present experiment the drop in final plant weight, however, was much greater than expected (TABLE 10). The reason may be that the plants at $10^{\circ} \mathrm{C}$

TABLE 9. Acceleration of the rates of growth ${ }^{1}$ and development ${ }^{2}$ at a rise in temperature

\begin{tabular}{|c|c|c|c|c|c|c|c|c|}
\hline $\begin{array}{l}\text { Rise in temperature } \\
10-16^{\circ} \mathrm{C}\end{array}$ & $\begin{array}{l}\text { Spring } \\
\text { rye }\end{array}$ & $\begin{array}{l}\text { Spring } \\
\text { wheat }\end{array}$ & $\begin{array}{l}\text { Spring } \\
\text { barley }\end{array}$ & Oats & Peas & Flax & Maize & Beans \\
\hline $\begin{array}{l}\text { Rate of growth .... } \\
\text { Rate of development }\end{array}$ & $\begin{array}{l}1,4 \\
1,6\end{array}$ & $\begin{array}{l}1,4 \\
1,8\end{array}$ & $\begin{array}{l}1,7 \\
1,6\end{array}$ & $\begin{array}{l}1,2 \\
1,7\end{array}$ & $\begin{array}{l}1,6 \\
1,6\end{array}$ & $\begin{array}{l}1,2 \\
1,5\end{array}$ & - & $\overline{-}$ \\
\hline $\begin{array}{l}16-25^{\circ} \mathrm{C} \\
\text { Rate of growth .... } \\
\text { Rate of development }\end{array}$ & $\begin{array}{l}1,1 \\
1,5\end{array}$ & $\begin{array}{l}1,0 \\
1,3\end{array}$ & $\begin{array}{l}1,1 \\
1,2\end{array}$ & $\begin{array}{l}1,1 \\
1,3\end{array}$ & $\begin{array}{l}1,1 \\
1,4\end{array}$ & $\begin{array}{l}1,2 \\
1,3\end{array}$ & $\begin{array}{l}2,1 \\
1,7\end{array}$ & $\begin{array}{l}2,2 \\
1,9\end{array}$ \\
\hline
\end{tabular}

1 Number of days in which the dry weight increased tenfold at $10^{\circ} \mathrm{C}\left(16^{\circ} \mathrm{C}\right)$ divided by the same value at $16^{\circ} \mathrm{C}\left(25^{\circ} \mathrm{C}\right)$.

Number of days from emergence to flowering at $10^{\circ} \mathrm{C}\left(16^{\circ} \mathrm{C}\right)$ divided by the same value
at $16^{\circ} \mathrm{C}\left(25^{\circ} \mathrm{C}\right)$.

TABLE 10. Dry weight (mg) of plants (tops) at the moment of heading (cereals) or first flowering attained at several constant temperatures

\begin{tabular}{ccrcrrrrr}
$\begin{array}{c}\text { Tempera- } \\
\text { ture }\left({ }^{\circ} \mathrm{C}\right)\end{array}$ & $\begin{array}{c}\text { Spring } \\
\text { rye }\end{array}$ & $\begin{array}{c}\text { Spring } \\
\text { wheat }\end{array}$ & $\begin{array}{c}\text { Spring } \\
\text { barley }\end{array}$ & Oats & Peas & Flax & Maize & Beans \\
10 & 8780 & 16240 & 12000 & 16210 & 4880 & 3160 & - & \\
16 & 4560 & 11100 & 6790 & 9750 & 3220 & 2160 & 13660 & 3650 \\
25 & 4050 & 7250 & 5400 & 7350 & 1970 & 1700 & 35150 & 4860 \\
\hline
\end{tabular}


finished their growth in much stronger daylight. They were harvested in June whereas the plants at $16^{\circ} \mathrm{C}$ and $25^{\circ} \mathrm{C}$ were harvested almost simultaneously in the beginning of May.

It is sure, however, that even under constant light conditions there is a general tendency for temperate zone crops (small cereals, peas, flax) to reach large proportions in cooler climates and this is the main reason why even the day-neutral varieties of these crops (for instance canning peas) are urable to give high yields when sown late in spring.

For maize and beans reverse relations prevail. When the temperature rises from $16^{\circ}$ to $25^{\circ} \mathrm{C}$ growth is accelerated relatively more than development (TABLE 9), so that the plants finally become larger (FIG. 4 and 6, TABLE 10). Hence maize and beans have the faculty of compensating and even overcompensating the acceleration of development at higher temperatures by a relatively still greater increase in daily growth rate. This faculty is probably typical of species originating from warm climates. Without it, annuals in tropical regions would never reach large proportions.

As TABLE 9 shows, the specific differences in temperature response are greater for growth rate than for development, and since growth rate is apparently mainly governed by the shoot/root-ratio it may be suggested that the distribution of material in the plant is the key to the important problem of the influence of temperature on plant production.

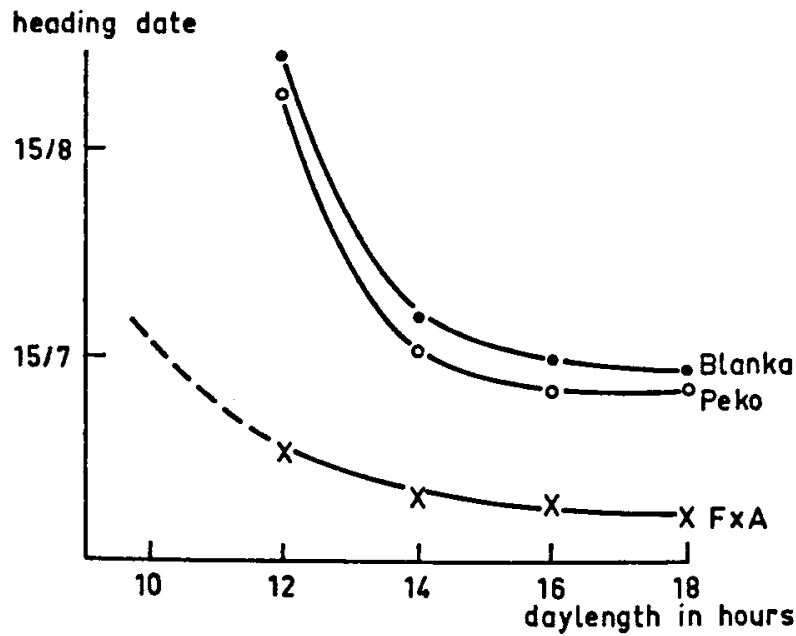

Fig. 8.

Influence of daylength on heading date of three springwheat varieties: Blanka (Swedish), Peko (German) and Florence $\times$ Aurore (Australian, grown in the Mediterranian region)

\section{The impact of photoperiodicity on yield}

The final yield of a crop is largely determined by its longevity. For instance, it is well known that a late potato variety can produce more than an early one. Longevity, however, depends on phasic development, and this in turn is influenced by climatic factors. Consequently temperature and light conditions have both an indirect and direct impact on yield. The influence of temperature on development has already been demonstrated in the preceeding section. The role of daylength will now be discussed.

The length of the juvenile stage largely determines the size a plant reaches at flower- 
INFLUENCE OF TEMP. AND LIGHT COND. ON DRY-MATTER DISTRIB., DEVELOPM. RATE AND . .

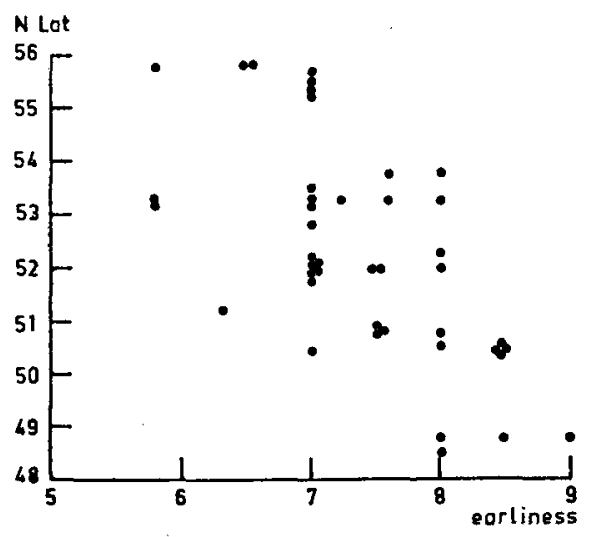

Fig. 9.

Relation between degree of latitude of the breeding station and earliness for winterwheat varieties grown in the Netherlands

ing (or at tuber initiation in the case of potatoes) which is generally the form that decides the ultimate size. When a plant is stimulated by an optimal daylength it has a short juvenile stage, is limited in size and ripens early. It is obvious, therefore, that the daylength optimal for rate of development is not optimal for production. The reverse is truer, viz. high yields require a long juvenile stage. It is no accident that the tobacco variety in which GARnER and Allard discovered photoperiodicity (or rediscovered it after KLEBS) bears the name Maryland Mammoth. The large proportions reached by this variety in long days is typical of a plant in a daylength which does not stimulate flowering.

The great significance of photoperiodical response for yields in agricultural practice has been emphasised by RAsumov (1930). He pointed out that late sowing in spring (in longer days) speeds up development and thus reduces yields in long-day plants (for example oats), whereas a short-day crop (millet) shows the reverse. This effect has since been demonstrated for several crops (van OORSchot, 1960). Fig. 7 gives another example of a long-day plant (poppy). These plants all received 12 hours of daylight. In several treatments day was prolonged to $13-14-15-16-17$ hours by weak fluorescent light. As a result plant size and longevity decreased in this sequence. Early ripening gives lower yields but, on the other hand, is esteemed in practice for technical reasons. The daylength giving an optimal development from an agricultural point of view should therefore be a compromise. For the poppy variety shown in FIG. 7 it may correspond to a daylength of about 14 hours, giving a fair plant which is still not too late in ripening. 14 hours is approximately the daylength received by young plants in April at our latitude when they become sensitive to photoperiod and the developmental rhythm is determined.

This implies that such a variety grown in Scandinavia, where in the seedling stage it would have a daylength of $16-17$ hours, would be far too early to give a good yield. On the other hand it would be very late in subtropical regions with their relatively short days. This means that each crop variety responding to daylength is restricted to a definite latitude for an optimal rhythm of development from an agricultural point of view.

Consequently there is a wide variation in daylength response between regional varieties of one crop. It has been shown (Doroshenko, 1927; Doroshenko and Rasumov, 1929) that Russian cereal varieties are adapted in daylength response to the latitudes 
where they are grown. For Western Europe the same has been demonstrated for wheat (FEEKES, 1941).

FIG. 8 gives an example from own experiments. The spring wheat variety Peko shows approximately the same daylength response as the poppy variety from FIG. 7 . From an agricultural point of view developmental rhythm for this variety is optimal in a daylength of 14 hours. This daylength prevails in the Netherlands at the time when the young plants become sensitive to photoperiod (April). This is of decisive importance for the good results obtained with this variety. In the experiment recorded in FIG. 8 the treatment with a daylength of 14 hours headed on July 15. The Scandinavien-bred variety Blanka has the same heading date (and therefore a good developmental rhythm) in the daylength of about 16 hours which prevails in Southern Scandinavia when spring wheat emerges. In our experiment the Australian variety Florence $\times$ Aurore, which is widely grown in the Mediterranian region as a winter crop, headed on July 15 in a daylength of about 11 hours (by extrapolation). This is exactly the photoperiod it receives in the field in February when the young plants are in the sensitive stage.

The well-known experience that wheat varieties from the north grown in the Netherlands are "late", whereas French varieties are "early" can also be explained by daylength response. For northern forms our daylength is "short", for French varieties "long". It could be shown that figures for "earliness" given to winter wheat varieties in the Netherlands "List of Varieties" are correlated to the latitude where they are bred (FIG. 9). This implies that a universal variety of a crop with a clear daylength response is an impossibility. A relationship of the kind shown in FIG. 9 could not be established for spring barley. Barley, although a long-day plant, has a far weaker response than wheat, oats and rye. This is also the reason why it is acceptable as a catch crop. When sown late in spring (in long days) it maintains a reasonable growth period.

Difficulties with maize in northern regions are connected with its short-day habit. For this crop in particular the breeding of day-neutral forms is imperative. It could be shown that such forms are quite common in collections of land varieties.

From the agricultural point of view daylength response is as important for potatoes as for seed crops (BoDlAENDER, 1958). All varieties grown in the Netherlands are accelerated in tuber formation by short day. In 12-13 hours light plants have a short juvenile phase. This means that tuber growth begins early. As a result the haulm remains limited in size, does not flower and ripens early. High yields are only obtained in long days when tuber initiation is retarded, enabling the haulm to reach a large size and a long growth period. It was shown by BODLAENDER (personal communication) that potatoes planted in March for early consumption are accelerated in tuber formation by the relative short days during emergence in April. This is of practical significance for this type of crop where earliness is more important than yield.

In mountainous tropical and subtropical regions with their shorter days Dutch potato varieties develop too rapidly and are unable to obtain the yield of the temperate zone, but they may be esteemed owing to their freedom from diseases. According to unpublished results obtained by BODLAENDER the important export variety Alpha shows a weaker response to daylength than other Dutch varieties and this may contribute to its good performance in southern regions. 
Bakhuyzen, H. L. VAN DE SANDE

Belikov, P. S., M. V. MOTORINA and E. B. KuRKova

Bodlaender, K. B. A.

BrouWER, R.

Doroshenko, A. V. and V. I. RAsumov

Downs, R. J., S. HeNDRICKS and $\mathbf{H}$. $A$. BORTHWICK

FeEkes, W. GaAstra, P.

Heath, O. V. S., and F. C. Gregory

Khalil, M. S. H.

LUNDEGARDH, $\mathbf{H}$.

Miller, E. C.

OORschot, J. L. P. VAN

Rasumov, V. I.

WATSON, D. J.

WittenRoOd, H. G.

\section{REFERENCES}

1937 Studies on wheat grown under constant conditions. Miscell. Publ. No. 8 of Ford Research Inst., Stanford Univ. of Cal.

1961 Intensity of photosynthesis in different varieties of Triticum. Proc. Tim. Agr. Ac. 5 (42), 44-54 (Russian).

1958 De invloed van verschillende daglengten op de ontwikkeling van de aardappel. Jaarboek I.B.S. 1958, 45-57.

1959 De invloed van de temperatuur op de ontwikkelingscyclus van erwten. Jaarboek I.B.S. 1959, 17-26.

1927 Photoperiodism of some cultivated forms in connection with their origin. Bull. Appl. Bot. Gen. and Pl. Breeding No. 17, 167-220 (Russian).

1929 Photoperiodism of some cultivated forms in connection with their geografic origin. Bull. Appl. Bot. Gen. and Pl. Breeding No. 22, 274-284 (Russian).

1957 Photoreversible control of elongation of Pinto beans and other plants under normal conditions of growth. Bot. Gaz. 118, 199-208.

1941 De tarwe en haar milieu. Versl. van de T.T.C. 17, 597-599.

1959 Photosynthesis of crop plants as influenced by light, $\mathrm{CO}_{2}$, temperature and stomatal diffusion resistance. Meded. Landb. hogesch. Wageningen 59 (13), 1-68.

1938 The constancy of the mean net assimilation rate and its ecological importance. Ann. Bot. 2, 811-818.

1956 The interrelation between growth and development of wheat as influenced by temperature, light and nitrogen. Thesis. Wageningen Agr. Univ.

1954 Klima und Boden. 4th edition, 135-136.

1939 A physiological study of th winter wheat plant at different stages of its development. Kansas State College of Agr. Bull. No. 47.

1960 Effect of daylength upon growth and development of spinach. Meded. Landb.hogesch. Wageningen 6 (18), 1-10.

1930 Uber die photoperiodische Nachwirkung in Zusammenhang mit der Wirkung verschiedener Aussaatterminen auf die Pflanzen. Planta. 10, 345-377.

1947 Comparative physiological studies on the growth of field crops. I. Variations in N.A.R. and leaf area between species and varieties and within and between years. Ann. Bot. NS. $11,41-76$.

1957 Grafische voorstelling van de ontwikkeling van een plant. Jaarboek I.B.S. 1957, 87-94. 